Article

\title{
A Soft Systems Methodology for Business Creation: The Lost World at Tyseley, Birmingham
}

\author{
Marianna Cavada ${ }^{1,2, *}$, Chris Bouch ${ }^{2}$, Chris Rogers ${ }^{2}$, Michael Grace ${ }^{3}$ and Alexander Robertson ${ }^{4}$ \\ ${ }^{1}$ Lancaster Institute for Contemporary Arts, School of Architecture, University of Lancaster, Lancaster, LA1 4YW, UK; \\ E-Mail:m.cavada@lancaster.ac.uk \\ 2 Department of Civil Engineering, University of Birmingham, Birmingham, B15 2TT, UK; E-Mails: c.bouch@bham.ac.uk \\ (C.B.), c.d.f.rogers@bham.ac.uk (C.R.) \\ ${ }^{3}$ Faculty of Computing, Engineering and the Built Environment, Birmingham City University, Birmingham, B4 7AP, UK; \\ E-Mail: michael.grace@bcu.ac.uk \\ ${ }^{4}$ Hay Mills Foundation Trust, Birmingham, B25 8DW, UK; E-Mail: ajrthorpe1@gmail.com \\ * Corresponding author
}

Submitted: 24 July 2020 | Accepted: 30 November 2020 | Published: 26 January 2021

\begin{abstract}
Much has been written about the benefits of green infrastructure, but securing the resources necessary for its development and long-term maintenance is often difficult. This article's premise is that, in general, people and organisations will take action to provide those resources when they can see value accruing to them; therefore narratives of value generation and capture (our definition of business models) are required to motivate and support that action. This article explores the application of soft systems methodology to the wicked problem of business model development in the context of a social enterprise, using a case study based on a piece of green infrastructure in the city of Birmingham, UK, called The Lost World. The research involved a workshop with several of The Lost World's key stakeholders and aimed at identifying: The Lost World's scope as a business; its potential value streams; and how they might be realised in a social enterprise. Analysis of the findings shows that while stakeholders can identify opportunities for their organisations, bringing those opportunities to fruition is difficult. The research demonstrates a compelling need for social entrepreneurs to act as catalysts and long-term enablers of the formulation and maintenance of businesses and business models-vital missing actors in the ambition to transform cityscapes.
\end{abstract}

\section{Keywords}

business model; green infrastructure; social enterprise; value

\section{Issue}

This article is part of the issue "Urban Planning and Green Infrastructure" edited by Paul Osmond (University of New South Wales, Australia) and Sara Wilkinson (University of Technology Sydney, Australia).

(C) 2021 by the authors; licensee Cogitatio (Lisbon, Portugal). This article is licensed under a Creative Commons Attribution 4.0 International License (CC BY).

\section{Introduction}

Much has been written about the benefits of green infrastructure, but securing the resources necessary for its development and long-term maintenance is often difficult. This article argues that, in general, people and organisations will take action to provide those resources when they can see value accruing to them and, therefore, narratives of value generation and capture, referred to herein as business models, are required to motivate and support that action. Typical business models with their focus on profit generation are unlikely to be suitable. Instead, social enterprise business models offer a potential way forward. They have specific social, environmental, and economic objectives extending well beyond concerns typically associated with corporate social responsibility (Seanor, Bull, \& Ridley-Duff, 2007), which may be better at supporting green infras- 
tructure by providing a hybrid approach that combines delivery of social purpose and maintenance of financial stability (Emam, 2016). However, whether profit-driven or social-enterprise, business model creation is a 'wicked problem' that "[does] not have a single outcome and [is] associated with a high degree of uncertainty," and "[is] dispersed amongst a host of actors [that requires] cocreation of knowledge to bridge social, environmental and economic tensions" (Henriques, 2018, p. 463). This can only be initiated by conversations that coalesce into a collective narrative (Pollastri et al., 2018). This article explores whether soft systems methodology (SSM) has a part to play in helping to address this complexity in the context of creating social enterprise business models for green infrastructure, and considers the potential role for social entrepreneurs. It starts with a review of the literature on the application of SSM to business models at the city scale, before narrowing the focus to green infrastructure and social enterprises. The research into novel approaches to business model creation is then described, including a workshop held with stakeholders to develop a social enterprise business model for a piece of green infrastructure in Birmingham, UK, called The Lost World. Finally, there is a discussion of the role for social entrepreneurs and conclusions are drawn.

\section{The Application of SSM to Social Enterprise Business Models in the Context of Green Infrastructure: A Literature Review}

\subsection{SSM at the City and Sub-City Scale}

Generating value in the development of local businesses requires a systematic view of the different approaches. In the literature review, we explored systematic thinking approaches and found 8,160 records in the Social Sciences Citation Index in the last five years. This yielded 698 papers in educational research, 641 in environmental sciences, 622 in management, and 612 in environmental studies. Due to the interest in green businesses specifically, relevant papers in environmental sciences were explored. These provided evidence of a shift to the system thinking approach, used by organisations to evaluate the challenges from different perspectives; for example, exploring the livelihood of an area and acceptance of sustainable projects (González, Sandoval, Acosta, \& Hena, 2016; Sánchez-García, Ramírez-Gutiérrez, Núñez-Ríos, Cardoso-Castro, \& Rojas, 2019). Often, this means that a single-view solution to address a challenge is no longer adequate; rather it requires a system-of-systems approach, and this usually applies to inherently-complex urban projects for which planning should consider solutions using mapping analysis (Bedinger, Beevers, Walker, Visser-Quinn, \& McClymont, 2020). This approach can support future design and foresee sustainable solutions, a practise which will educate future generations and advance sustainability science (Gray et al., 2019; Onat, Kucukvar, Halog, \& Cloutier, 2017). It is necessary to support the right conditions for mutual understanding between all those involved in commercial and sustainability projects (Ahlström, Williams, \& Vildåsen, 2020). A systems thinking approach helps in addressing issues of sustainability, for example when tackling climate mitigation and planetary wellbeing, and delivering sustainable solutions-a practise which requires, and supports willingness to sustain, political power in the future (Berry, Waite, Dear, Capon, \& Murray, 2018; Király, Köves, \& Balázs, 2017). All of this suggests that systematic thinking is taking the lead in the development of sustainable future solutions (Gu, Deal, \& Larsen, 2018; Williams, Kennedy, Philipp, \& Whiteman, 2017). These solutions should aim not at the methodological practises, but rather at the efficacy of their application; for example, not in the ways of how sustainable the products or services are, but whether the application of the solution or organisation will be sustainable in the future (Moldavska \& Welo, 2016; Patel \& Mehta, 2016).

Having established above that creating business models to generate and capture value is a 'wicked problem' due to the lack of a single outcome and a high degree of uncertainty, then an approach that is founded on 'advancing by learning' is necessary. SSM, often attributed to Checkland (Checkland \& Haynes, 1994; Checkland \& Scholes, 1999), offers a framework for the solution of such problems, which can be conceptualised at a high level as an iterative learning process as shown in Figure 1 (Bouch, Rogers, Powell, \& Horsfall, 2018). The process starts with a description of the real-world situation of concern: For example, creation of a sustainable green infrastructure business. Once the business is defined, stakeholders, stakeholder requirements, and value generation opportunities can be identified and synthesised into potential, purposeful activities for change, which can then be assessed against the existing system to see whether they are systemically desirable and culturally feasible. Implementing change completes the first iteration by creating a new real-world situation ready for further refinement.

A search of SSM literature published in the last five years found 201 records in the Social Sciences Citation Index, of which 100 concerned management, 38 operations research, 16 industrial engineering, and 15 interdisciplinary social science. SSM is mostly a knowledgelearning task between the participants, a process of exploration and observation (Caceres \& Wiesenborn, 2019). The literature suggests that approaching a 'soft' issue requires an explicit rather than implicit understanding of the issue itself, which acknowledges the context, and those involved-this requires a systems methodology (Hanafizadeh \& Ghamkhari, 2018). Equally, communication barriers are highlighted as an important consideration, interpretation may vary between those who conduct the research, and inter-organisational cultures can differ markedly, and so the systems analysis should be tested to identify these and similar problems of the method (Caceres \& Wiesenborn, 2019; Nguyen, 


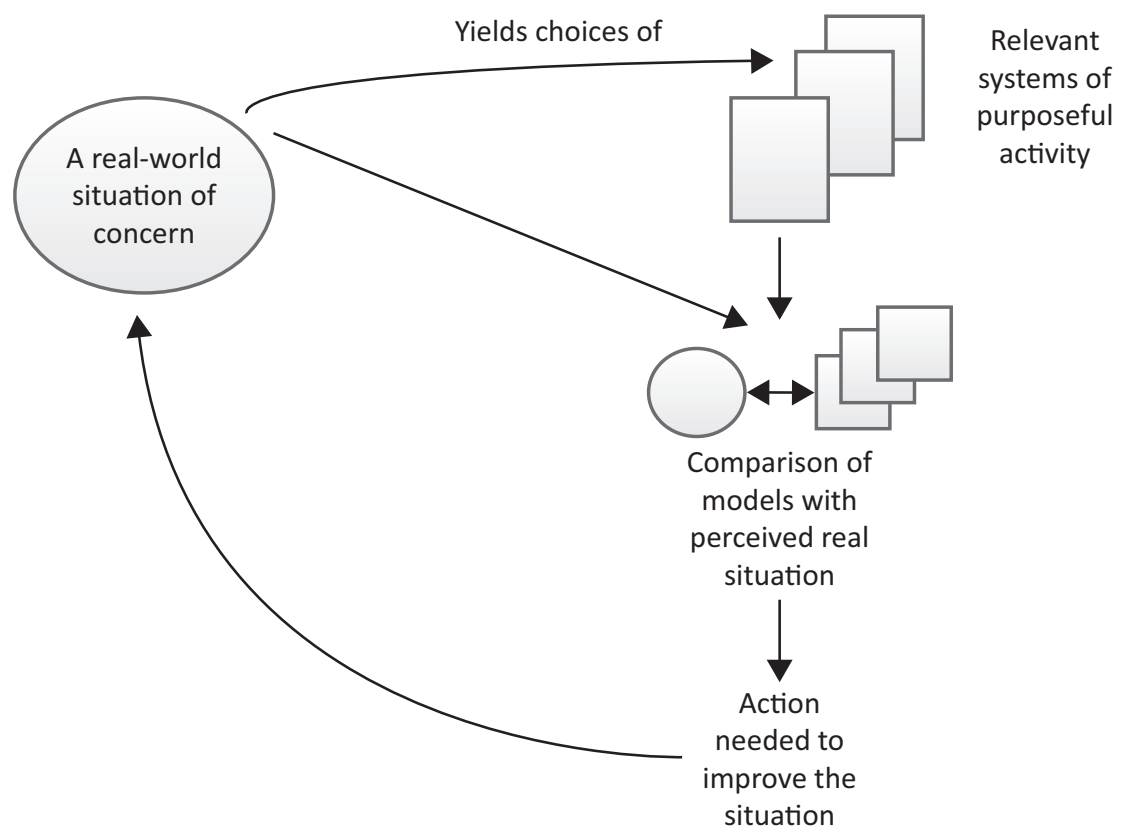

Figure 1. A simplified depiction of SSM. Source: Adapted from Checkland and Scholes (1999).

Scognamillo, \& Comer, 2019). Likewise, social norms, political views, and leadership style can affect SSM-this is a matter to explore among stakeholders (Kish, Bunch, $\& X u, 2016)$.

The literature review showed that significant research has been carried out over the past 15 years elaborating on the high-level SSM stages described above. A wide range of these papers has recently been brought together as the UKCRIC Infrastructure and Cities Methodology, where UKCRIC is the United Kingdom Collaboratorium for Research on Infrastructure and Cities (UKCRIC, 2021). The steps in the methodology, which was originally developed to address city-scale problems, are set out in Table 1. Entries 1 to 4 in Table 1 correspond to that part of Figure 1 identifying the real-world situation. Entry 5 covers the SSM activity of identifying relevant systems of purposeful activity. Entries 6 to 14 relate to the SSM's comparison of models with the perceived real situation; and, entries 15 to 17 are all about the action need in SSM to improve the real-world situation.

\subsection{Social Enterprise}

A search on social enterprise in Web of Science found around 400 papers of which 150 were on management, 120 on business, 64 on environmental studies, and 59 on environmental sciences. In order to help understand how social enterprise can be created, the literature review concentrated on the more highly cited (over 20 citations) management papers to identify key issues in the management of the social enterprise. For example, Tracey and Philips (2015) concluded that a lack of responsibility across all levels of social enterprise could negatively impact on the social value of the organisation. The aim is for value generation to be a sustainable practice and for it to influence multiple sectors over time to support the local economy as whole-this requires local stakeholders' involvement, i.e., from those who probably have knowledge of resources and also the wider political agenda (Altinay, Sigala, \& Waligo, 2016; Dey \& Teasdale, 2016). In this way, decision-making responsibility can be distributed to ensure sustainability in business development (Akemu, Whiteman, \& Kennedy, 2016). To overcome the uncertainty inherent in social enterprises, in which social aspects are the key components, communication between stakeholders is a vital consideration (Bontis, Ciambotti, Palazzi, \& Sgro, 2018). While a democratic approach between the stakeholders is essential, communication at a senior level to support diversity and innovation and ensure the sustainability of the business as a social enterprise is also required (Crucke \& Knockaert, 2016). In socially responsible enterprises, the action model should be easy to understand and it should be possible to explore interdependencies and limitations in a transparent manner (Sánchez, Bolívar, \& Hernández, 2017; Zahra, Gedajlovic, Neubaum, \& Shulman, 2009). This will allow the aims and objectives of the organisation or business to include identification of opportunities via a bottom-up approach (Choudrie \& Zamani, 2016). While traditional organisations aim for a business approach, the role of the social-stakeholders can be complementary, such as by helping to explain how to be sustainable in the future (Lee, Herold, \& Yu, 2016). The challenge of financial planning will remain a concern, but the 'why and how' can positively contribute to the long-term social welfare (Wry \& York, 2015). An overall shift of the business model towards social enterprise requires an understanding and exploration of limitations, and building stakeholders' trust in this different approach (Dey \& Teasdale, 2016; Upward \& Jones, 2016). 
Table 1. Summary of the UKCRIC infrastructure and urban systems methodology.

\begin{tabular}{|c|c|c|}
\hline & Lessons from Cities Research & Evidence Base References \\
\hline 1 & $\begin{array}{l}\text { Address a specific infrastructure and urban system problem, } \\
\text { assemble an appropriately broad, multi-disciplinary, } \\
\text { multi-sectoral group of potentially interested parties, } \\
\text { including users of the outcomes }\end{array}$ & $\begin{array}{l}\text { Rogers et al. (2014) } \\
\text { Wilson, Tewdwr-Jones, and Comber (2019) }\end{array}$ \\
\hline 2 & Understand deeply the aspirations of the city and its people & $\begin{array}{l}\text { Rogers (2018) } \\
\text { Rogers and Hunt (2019) }\end{array}$ \\
\hline 3 & Diagnose fully the problems & Leach, Mulhall, Rogers, and Bryson (2019) \\
\hline 4 & $\begin{array}{l}\text { Establish the baseline performance of the city in terms of its } \\
\text { sustainability, resilience, and liveability }\end{array}$ & $\begin{array}{l}\text { Bouch and Rogers (2017) } \\
\text { Leach et al. (2016) } \\
\text { Leach, Lee, Hunt, and Rogers (2017) }\end{array}$ \\
\hline 5 & Apply ingenuity to create solutions to the problem & $\begin{array}{l}\text { Caparros-Midwood, Barr, and Dawson (2017) } \\
\text { Powell, Glendinning, and Dawson (2018) } \\
\text { Rogers (2018) }\end{array}$ \\
\hline 6 & $\begin{array}{l}\text { Assess the impact of the interventions on the city's } \\
\text { infrastructure and urban systems }\end{array}$ & $\begin{array}{l}\text { Leach et al. (2017) } \\
\text { Leach, Rogers, Ortegon, and Tyler (2019) }\end{array}$ \\
\hline 7 & $\begin{array}{l}\text { Conduct a futures analysis to explore whether the interventions } \\
\text { are vulnerable to future contextual change (i.e., are resilient) }\end{array}$ & $\begin{array}{l}\text { Lombardi et al. (2012) } \\
\text { Rogers, Lombardi, Leach, and Cooper (2012) }\end{array}$ \\
\hline 8 & $\begin{array}{l}\text { Use numerical and scenario modelling to predict near and far } \\
\text { future need for infrastructure and urban system services: } \\
\text { Do solutions meet these needs? }\end{array}$ & $\begin{array}{l}\text { Hall, Tran, Hickford, and Nicholls (2016) } \\
\text { Ives, Simpson, and Hall (2018) } \\
\text { Rogers et al. (2012) } \\
\text { Rogers (2018) }\end{array}$ \\
\hline 9 & Make the case for change & $\begin{array}{l}\text { Leach et al. (2017) } \\
\text { Leach, Rogers, et al. (2019) }\end{array}$ \\
\hline 10 & Develop a suite of alternative 'business models' & $\begin{array}{l}\text { Bouch and Rogers (2017) } \\
\text { Bryson et al. (2018) } \\
\text { Rogers (2018) }\end{array}$ \\
\hline 11 & $\begin{array}{l}\text { Understand all of the dimensions of governance (formal and } \\
\text { informal) relevant to the intervention and the context }\end{array}$ & $\begin{array}{l}\text { Honeybone, Collins, Barnes, and Cosgrave (2018) } \\
\text { Leach, Rogers, et al. (2019) } \\
\text { Rogers (2018) }\end{array}$ \\
\hline 12 & $\begin{array}{l}\text { Trial infrastructure and urban systems interventions in } \\
\text { UKCRIC's Laboratories }\end{array}$ & \\
\hline 13 & $\begin{array}{l}\text { Trial infrastructure and urban systems interventions in } \\
\text { UKCRIC's Urban Observatories }\end{array}$ & \\
\hline 14 & $\begin{array}{l}\text { Trial infrastructure and urban systems interventions in } \\
\text { UKCRIC's Modelling \& Simulation Facilities }\end{array}$ & \\
\hline 15 & Influence policy & $\begin{array}{l}\text { Honeybone et al. (2018) } \\
\text { Rogers et al. (2014) }\end{array}$ \\
\hline 16 & Influence practice & $\begin{array}{l}\text { Leach, Rogers, et al. (2019) } \\
\text { Rogers (2018) }\end{array}$ \\
\hline 17 & Inform and engage the public & \\
\hline
\end{tabular}

\subsection{Green Infrastructure}

Sustainability is deeply rooted in the UK Government's strategy 'A Green Future: Our 25 Year Plan to Improve the Environment' (Defra, 2018), which aims to bring the envi- ronment to future generations in a better state than it is today, through the benefits of natural as well as social and economic capital. Natural capital needs to be supported by green infrastructure placed in the urban context (Arup, 2014), making a vital contribution to more 
sustainable living and providing wider benefits to urban living while mitigating some of its adverse consequences, features that require more conscious inclusion in the smart cities discourse (Cavada, Hunt, \& Rogers, 2016; Mora \& Deakin, 2019). Yet green infrastructure is a system that underpins a wider agenda in sustainability; an urban ecosystem that is healthy and resilient contributes to biodiversity conservation and benefits human populations through the maintenance and enhancement of ecosystem services in a systematic approach to enhance living in urban contexts (Naumann, McKenna, Kaphengst, Pieterse, \& Rayment, 2011). Urban green infrastructure supports people in a number of ways: for example, regulating urban microclimates, providing recreational facilities, bolstering flood resilience measures, supporting local food supplies, improving water and air quality, and fostering urban biodiversity (Arup, 2014; Breuste, Artmann, Li, \& Xie, 2014). However, this green infrastructure system would be difficult to fund and maintain, because funders often find it difficult to capture a share of the benefits arising. Economic value, as perceived by investors, is a matter of financial return and maximisation of land value is often a primary driver of urban development (Arup, 2014). Along with the problem of value capture lie the difficulty of securing political will, governance issues and competing priorities, while austerity measures can only make funding for sustainability and natural environment benefits more challenging (Centre for Cities, 2019; House of Commons, 2017).

Similarly, natural capital accounting techniques, developed to create stronger business cases in the urban realm, have been met with limited success. Natural capital accounting can quantify "natural capital stocks and service flows to determine the nature and scale of [the benefits generated], and how they vary over time, and whether management and use of natural capital is sustainable" (Faccioli, McVittie, Glenk, \& Blackstock, 2018, p. iv). This is linked to the idea of the developing green economy and the emergence of markets for ecosystem services (Sullivan, 2014). However, while natural capital accounting can help to measure the potential benefits of green infrastructure, it does not make them any easier to realise, as illustrated by Hoelzinger and Grayson (2019). Using a natural capital accounting approach, they calculated a net present benefit of nearly $f 11$ billion from the green spaces managed by Birmingham City Council over a period of 25 years, but with many of the value 'streams' identified (for example, mental health benefits, air quality, biodiversity) difficult to capture. An alternative approach is to explore whether narratives of value generation and capture (business models) can be created to help support green infrastructure. This will allow stakeholders to create value and capture a share in the form of a social enterprise, with a sustainable approach (of social, environmental, and economic objectives) seeking to combine the delivery of social purpose and maintenance of financial stability (Emam, 2016; Seanor et al., 2007; Zott \& Amit, 2010).

\section{Aim and Objective of Study}

The aim of the research is to explore whether SSM can contribute to the development of business models to support the provision of urban green infrastructure. The objective is to demonstrate the role that SSM can play through a case study based on a piece of green infrastructure in Birmingham, UK, called The Lost World.

\section{The Lost World}

The Lost World extends to approximately 18.5 hectares in southeast of Birmingham, straddling the boundary between Tyseley \& Hay Mills and Balsall Heath council wards. It is an urban area that still tries to protect its distinctive character and develop local economic activity and involvement. The case study involved a workshop with the principal stakeholders. Figure 2 shows The Lost World in relation to Birmingham city centre, while Figure 3 shows that The Lost World is an oasis of 'green' in comparison with the surrounding industrial areas.

The aim of the workshop was to involve interested stakeholders from the local community, who could articulate their knowledge of and future aspirations for the area. The academic team was keen to understand and explore with them their interest in the area, identify value opportunities for their organisations and understand challenges in realising this value, and together generate value for the future of The Lost World.

\section{Shaping the Future of Tyseley \& Hay Mills: Outcomes from the Lost World Workshop}

The Tyseley area is considered one of the most deprived wards in the City of Birmingham and is within the $10 \%$ most deprived wards in the UK (Birmingham City Council, 2019). The local authority councillor for Tyseley \& Hay Mills, the Hay Mills Foundation Trust and Webster \& Horsfall Holdings Limited, a long-established wire manufacturing company and owner of Tyseley Energy Park (TEP), have been driving the economic regeneration in the area based on low carbon, alternative energy technologies; however, importantly, they also have a desire to improve the environmental quality of Tyseley. The Hay Mills Foundation Trust is a charity established in 2015 by Webster \& Horsfall Holdings Limited. Its principal activity is creating a historical record of the Webster and Horsfall operations, but it also has a remit to engage with the local community to promote connections between the company and the local community (TEP, 2020). Table 2 lists the stakeholders who were invited to, and took part in, the workshop and their respective visions. It shows that most of the participants' visions/missions relate strongly to an environmentally sustainable future of the Tyseley \& Hay Mills area.

Twenty-four stakeholders representing the above organisations took part in a half-day workshop on 24th 


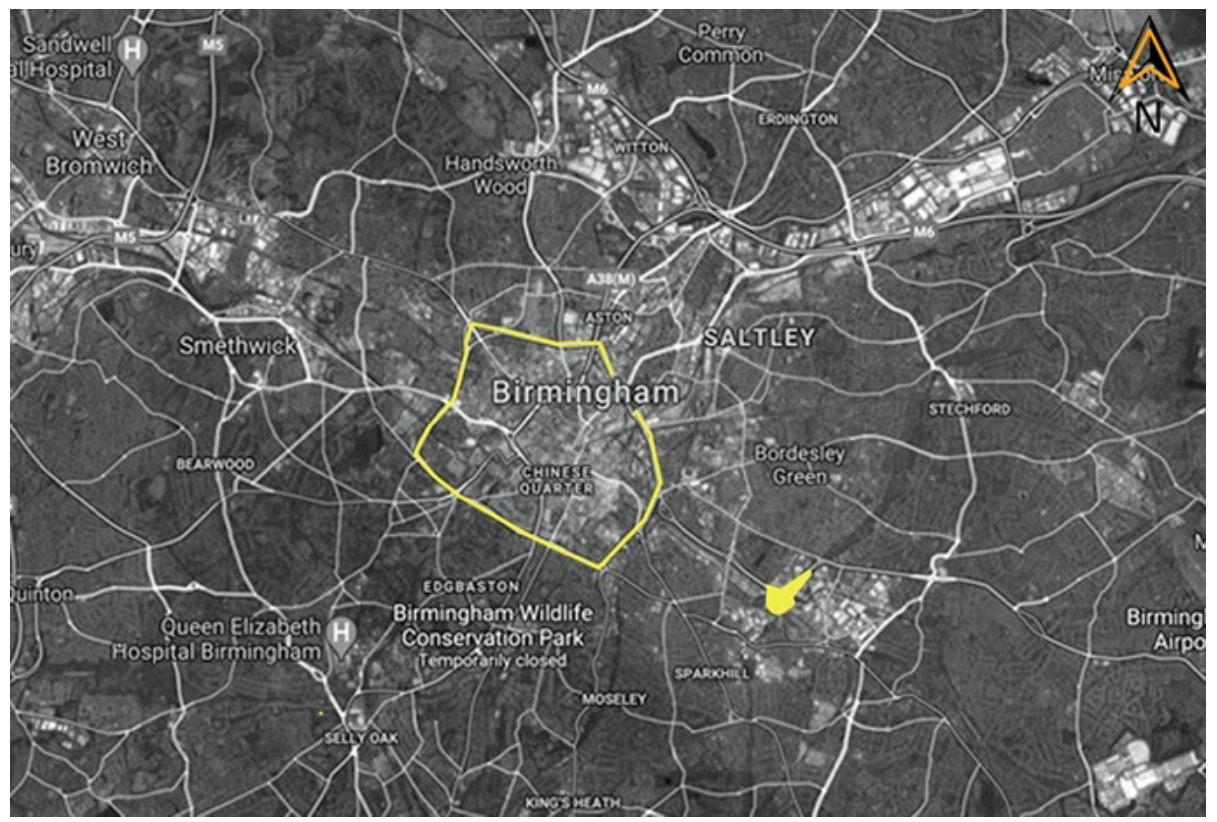

Figure 2. The Lost World in relation to Birmingham city centre.

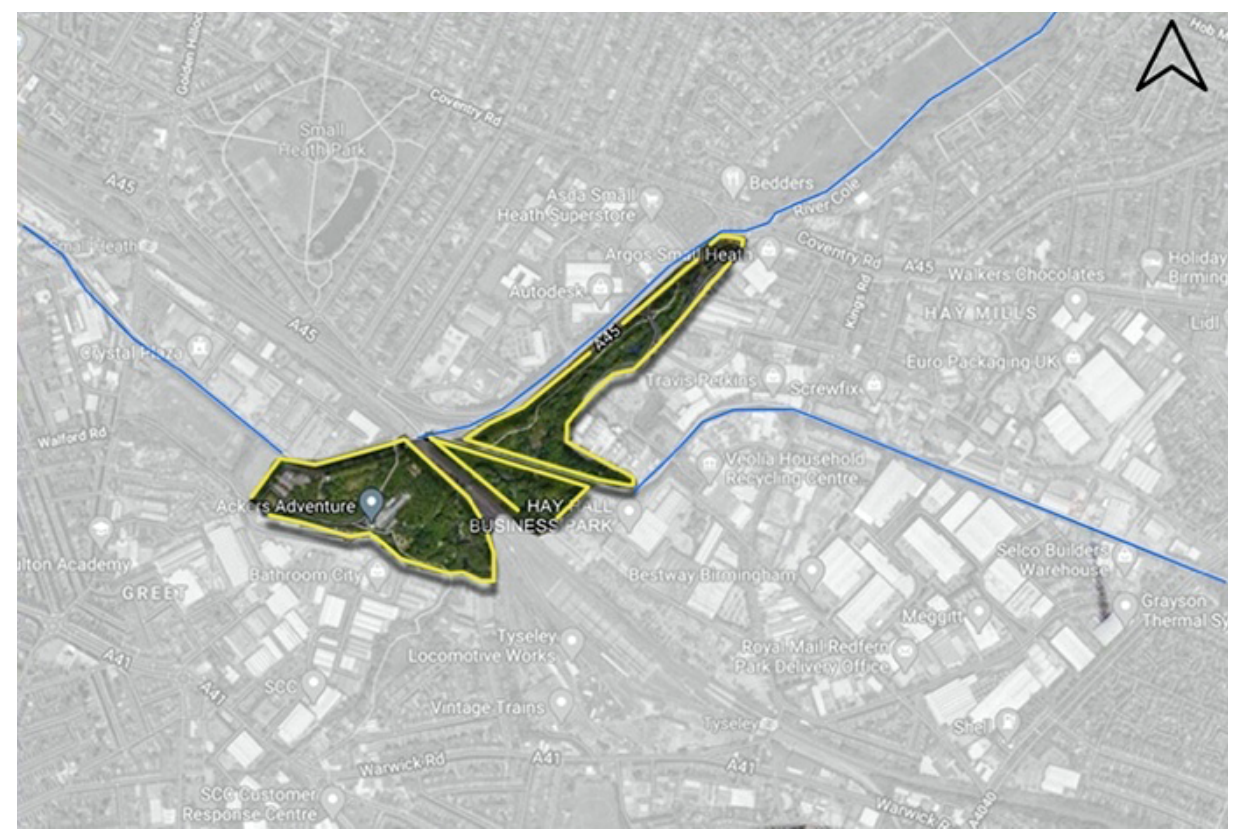

Figure 3. The Lost World showing the Grand Union Canal (running E-W) and the River Cole (running $\sim \mathrm{SE}-\mathrm{NW}$ ).

October 2019 to explore what The Lost World might be. The workshop was facilitated by Hay Mills Trust, along with the research team (three from the University of Birmingham and one from Birmingham City University). The stakeholders were arranged into four mixed groups (labelled red, green, yellow and blue; these colours are used in the tables below) and asked to explore the following questions. Session 1: What areas of interest can you see in The Lost World? Session 2: What sort of valuegenerating opportunities can you see in The Lost World? Session 3: What steps need to be taken to help The Lost World generate value for your organisation, and what things could get in the way?

\subsection{Session 1: Areas of Interest and Boundaries}

In addressing this question, the stakeholders were asked to think about where The Lost World's borders might best be placed in order to support the visions/missions of the organisations they were representing. Within those borders, they identified factors they felt might make an important contribution to their organisation's existing operations. Areas of interest are shown in Figure 4. A central area combining parts of the canal and greenery (yellow strip) generated the most interest as the focal point of future activity, both for itself and considering the outward views to the surroundings. Other desirable features 


\section{COGITATIO}

Table 2. The Lost World stakeholders and their visions/missions.

\begin{tabular}{|c|c|}
\hline Stakeholder (reference) & Stakeholder Visions/Missions \\
\hline West Midlands Police (2020) & Prevent crime and protect the public \\
\hline Ackers Adventure (2020) & Provision of leisure outdoor activities \\
\hline Birmingham Open Spaces Forum (2020) & Having an interest in the City's parks and open spaces \\
\hline ND Landscape Architects Ltd (2020) & $\begin{array}{l}\text { Innovative landscape architecture, garden design and } \\
\text { arboriculture practice }\end{array}$ \\
\hline St Cyprian's Church (Church of England, 2020) & An open all-religious community \\
\hline Birmingham Energy Institute (2020) & Academic Centre of Excellence on energy \\
\hline TEP (2020) & Drive industrial growth alongside green technologies \\
\hline Environment Agency (2020) & Create better places for people and wildlife \\
\hline Canal and River Trust (2020) & Sustain and revitalise British waterways \\
\hline Inspired Steps (2020) & Changing communities towards sustainable living \\
\hline Vintage Trains (2020) & $\begin{array}{l}\text { Preserve and demonstrate steam locomotives; museum attraction } \\
\text { based in Tyseley }\end{array}$ \\
\hline Birmingham Education Partnership (2020) & $\begin{array}{l}\text { Secure a deeply good academic, social and civic education for every } \\
\text { child and young person living in Birmingham }\end{array}$ \\
\hline Hay Mills Foundation Trust (2020) & $\begin{array}{l}\text { Engage with the local community to promote the history and heritage } \\
\text { (particularly of Webster \& Horsfall) on the Hay Mills site }\end{array}$ \\
\hline Birmingham City Council (2017) & An enterprising, innovative, and green city \\
\hline Local councillor & Serve the local community \\
\hline Local residents & Interested in the area \\
\hline
\end{tabular}

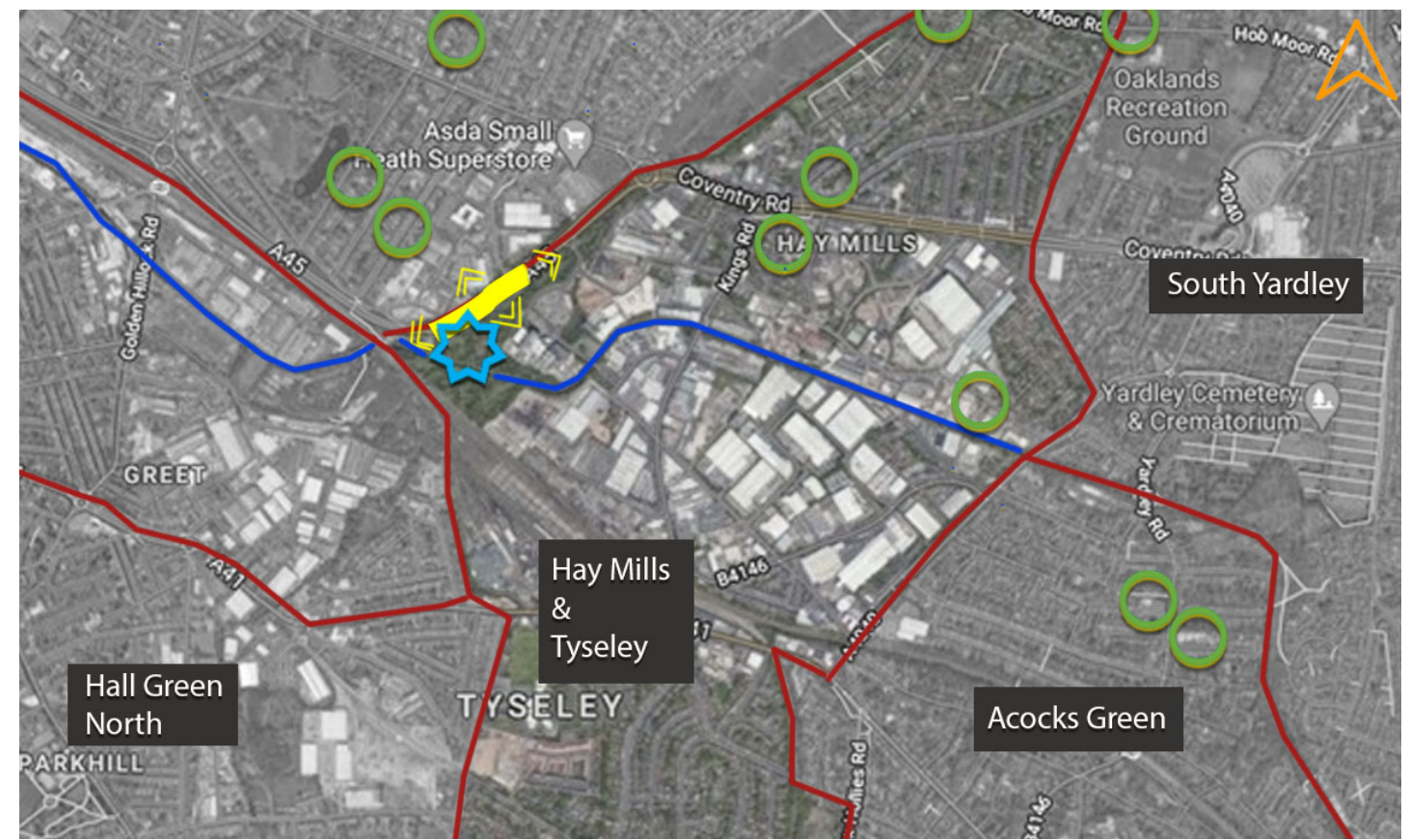

Figure 4. Stakeholder area mapping combined central blue-green space (yellow), an innovation hub (blue), and educational facilities (green). 
identified included an innovation hub (blue star) to bring industrial, business, and local knowledge into an accessible forum, with a reach into the adjoining extended industrial area of TEP, and enhanced cohesion amongst educational facilities in the area, which were considered to extend sporadically across the north and northwest parts of the wider area (green circles). Notably, the discussion extended beyond the given site boundaries, indicating the area's potential to influence the surrounding areas.

Four main areas of stakeholder interest emerged during the discussions in each of the four groups: communi- ty building, the various forms of value provided by the area's greenspace, the opportunities offered by TEP to the local community, and educational opportunities arising from the local area. Table 3 provides brief summaries of the discussions transcribed by the researchers following the workshop.

\subsection{Session 2: Value Generating Opportunities}

In Session 2, stakeholders were presented with an introduction and explanation of the structure and development of the Generic Value Map shown in Figure 5 (Bouch

Table 3. Goals and stakeholder areas of interest in The Lost World.

\begin{tabular}{|c|c|}
\hline Goals & Stakeholder Areas of Interest \\
\hline Community building & $\begin{array}{l}\text { - A community centre in the area centred on St Cyprian's church } \\
\text { - Reaching out from St Cyprian's church to connect with local schools and faiths } \\
\text { - The local communities around the existing industries and the opportunity for industry to } \\
\text { participate in strengthening connections } \\
\text { - Tyseley \& Hay Mills and Small Heath council wards } \\
\text { - Working collaboratively to create an area of safety } \\
\text { - The catchment area from which shoppers are drawn to Tyseley's store } \\
\text { - Generally, interest in the local community }\end{array}$ \\
\hline Valuing greenspace & $\begin{array}{l}\text { - The opportunity to link and develop (a) green corridor(s) } \\
\text { - The Akers site is available to promote health and wellbeing (H\&WB) } \\
\text { - A blue corridor and green corridor from Heritage Trains to Akers, providing visiting } \\
\text { opportunities and improved access } \\
\text { - A green corridor linking the Vintage Trains site to Heybarnes, improving access and increasing } \\
\text { visitor numbers } \\
\text { - The canal itself and the land bordering it to a distance of one kilometre on either side provides } \\
\text { valuable leisure and educational opportunities } \\
\text { - The River Cole Valley: improving access for safety, visiting, and cultural purposes } \\
\text { - Flood risk areas along the River Cole valley } \\
\text { - River Cole connected catchments, upstream and downstream } \\
\text { - Opportunities for public access to the River Cole } \\
\text { - The green corridors along the River Cole and Grand Union Canal }\end{array}$ \\
\hline $\begin{array}{l}\text { TEP and the } \\
\text { local community }\end{array}$ & $\begin{array}{l}\text { - Energy research \& innovation hub centred on TEP } \\
\text { - Sustainability centred on Tyseley Environmental Enterprise District } \\
\text { - Low carbon innovation centred on Tyseley Environmental Enterprise District } \\
\text { - Green transport centred on Tyseley Environmental Enterprise District } \\
\text { - The area around the existing factory and its potential for economic growth } \\
\text { - Heritage aspects of the area around the existing industries and the opportunity for industry to } \\
\text { maintain and build on them } \\
\text { - The linking of visitor attractions (canal, river, greenspaces) to create an integrated attraction } \\
\text { - Strengthening links between Birmingham's city green vision and The Lost World } \\
\text { - Strengthening links between industry and academia to support volunteer groups and secure the } \\
\text { long-term future }\end{array}$ \\
\hline Educational value & $\begin{array}{l}\text { - Opportunity to educate about and involve children in maintaining greenspaces } \\
\text { - Opportunity to involve parents in children's education } \\
\text { - Build career aspirations around sustainability and the environment } \\
\text { - Support schools by providing learning activities in the area (on both urban and green } \\
\text { environments) } \\
\text { - Opportunity to strengthen curricula in the local area } \\
\text { - Tyseley \& Hay Mills and Small Heath council wards to offer educational space }\end{array}$ \\
\hline
\end{tabular}




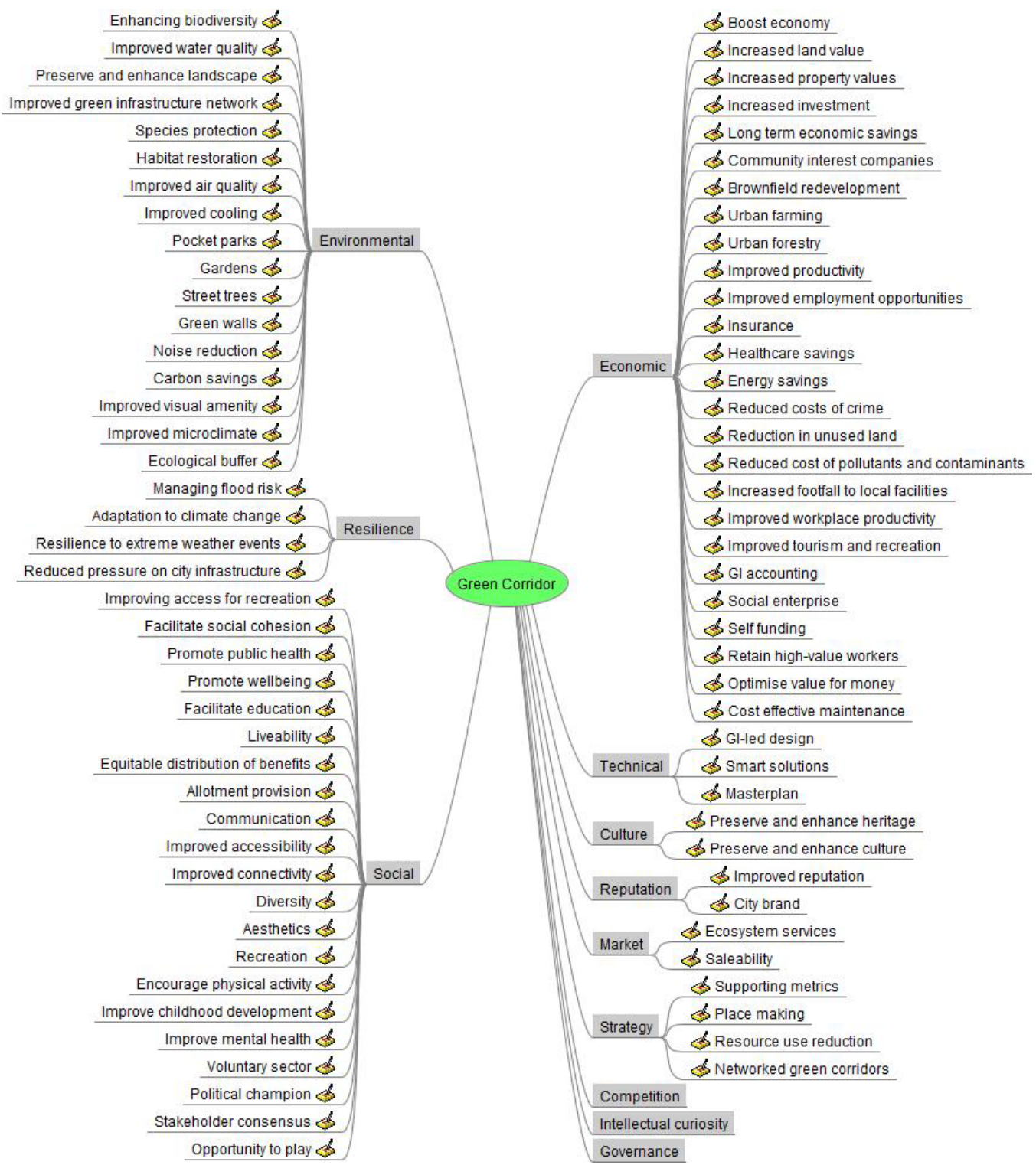

Figure 5. Generic value map identifying value generating opportunities for businesses.

et al., 2018). Through discussion, stakeholders identified 97 potential opportunities that were categorised into 25 areas by the research team. In general, all groups suggested opportunities (mostly around 20 each, although the yellow group suggested 37), providing a good indication of all voices being heard. Further analysis identified five high priority value-generating ideas (Table 4) and five lower priority value-generating ideas (Table 5). Initially the discussion centred around topics identified in Session 1 (e.g., a community hub and a research \& innovation hub), but now the discussions turned to a more focused approach on value generation, such as the benefits of social cohesion, improved $\mathrm{H} \& W B$, and visiting opportunities. In addition, opportunities were identified to inform established organisational structures and strategies, such as collaboration with the local Council (on Birmingham's Biophilic City status), resilience (insurance sector) and land value (commercial land development). The approach was that business models should evaluate and demonstrate the multiple benefits across economic, social, environmental and governance domains by doing things differently (e.g., designing and implementing initiatives to realise visions and ambitions) and show to the stakeholders how they could act in support their delivery (Cavada, Hunt, \& Rogers, 2017; Rogers, 2018).

\subsection{Session 3: Limitations and Opportunities for The Lost World}

In this session, each group discussed how the valuegenerating opportunities identified in Session 2 might be brought together to create a business model for The Lost World while delivering value to their own organisations. Both the green and blue groups focussed on a hub in collaboration with TEP. For them, green infrastructure was already considered to be included in TEP's visionthis now should work as a catalyst and extend beyond 
Table 4. High priority value-generating opportunities identified by the four stakeholder groups (denoted by different colours).

\begin{tabular}{|c|c|c|}
\hline Goals & Stakeholder Identified Value Generating Opportunities & Group \\
\hline \multirow[t]{9}{*}{ Social cohesion } & Community integration & \\
\hline & Community ownership & \\
\hline & Consultation for community empowerment & \\
\hline & Creation of community spirit & \\
\hline & Improve the attractiveness of the area & \\
\hline & Pride in area & \\
\hline & Getting people out of their area and silo & \\
\hline & Culture & \\
\hline & Resident ownership-collective responsibility & \\
\hline \multirow[t]{7}{*}{ Improved health \& wellbeing } & Amenity value for employers and tenants & \\
\hline & Social awareness and education bringing physical and mental health benefits & \\
\hline & Healthy lifestyles: encourage people to be outdoors more & \\
\hline & Actions to enhance wellbeing & \\
\hline & Improving the canal and towpath as a 'wellbeing' environment & \\
\hline & Calm environment & \\
\hline & Actions to enhance $\mathrm{H} \& W B$ & \\
\hline \multirow[t]{7}{*}{ Community hub } & Community interest and support enabling growth & \\
\hline & Engage the community to help keep the church open & \\
\hline & Connectivity & \\
\hline & Provision of a public house as a community-meeting place & \\
\hline & Attracting different audiences-all organisations community hub and space & \\
\hline & Community hub and space & \\
\hline & Invest in religious places & \\
\hline \multirow[t]{6}{*}{ Visitors } & Bring people into area & \\
\hline & Garden walks [leading to] increased visitor numbers & \\
\hline & $\begin{array}{l}\text { Increased use of the canal by people living in a 2-kilometre-wide corridor, } \\
\text { centred on the canal. }\end{array}$ & \\
\hline & Local tourism from city centre & \\
\hline & Generate income & \\
\hline & Business due to increased footfall & \\
\hline \multirow[t]{6}{*}{ Research and innovation hub } & Increase research impact & \\
\hline & Research and modelling of value & \\
\hline & Technology development & \\
\hline & Green technology & \\
\hline & New service providers & \\
\hline & Finding opportunities & \\
\hline
\end{tabular}

the point of focus to provide benefits to other areas, for example in reducing crime levels in the area. The yellow group spoke about a hub of a different kind: they focused on a community-based hub, one that could have the church at its centre, providing a spiritual connection to H\&WB. It was also suggested to provide connections and business opportunities for the hub, such as for
Ackers' leisure activities and for visitors. Leisure also provided the focus for the red group, which suggested that the River Cole should form part of the wellbeing strategy for the area. This strategy would aim to improve access and maintenance of the blue and green infrastructure and complement the Environment Agency's infrastructure improvement plan for the area. 
Table 5. Lower priority value-generating opportunities identified by the four stakeholder groups.

\begin{tabular}{ll}
\hline Goals & Stakeholder Identified Value Generating Opportunities \\
\hline Volunteering & Community to feel ownership and responsibility \\
Strategy & $\begin{array}{l}\text { Commonwealth Games would benefit from positive environmental improvements. } \\
\text { Align with City Council strategies. }\end{array}$ \\
Land value & Potential (commercial?) land value \\
Resilience & Improving local environmental resilience \\
Flood risk & Reducing flood risk \\
\hline
\end{tabular}

\section{Limitations and Opportunities for The Lost World}

The majority of stakeholders identified funding as being the biggest challenge. In the past, when funding was in place, it was often for a short duration and did not support a diverse range of business activities. This led to a tendency to focus on short-term initiatives as well as providing a constraint on aspirations for the long-term, sustainable future of The Lost World. Lack of specific business funding can also be a barrier. However, there are now opportunities to test initiatives for their alignment with wide-ranging visions and aspirations (Rogers \& Hunt, 2019) and for their long-term as well as short-term efficacy, notably using alternative future scenarios to test for resilience (Rogers, 2018). Alongside funding, communication was considered a major constraint. That there is no current space to bring stakeholders together, both in spatial and opportunity terms, was deemed to be the most important barrier to communication. However, this concern also applied to communication links aimed at the educational opportunities around the area, even though TEP and the University of Birmingham would appear to provide excellent opportunities.

It was emphasised that the green areas lacked a joined-up infrastructure, prohibiting access and benefitdelivery for many of the stakeholders. Such an infrastructure mechanism, via interconnected green corridors linking also to the river and canal, could be readily foreseen, but is yet to materialise. Interestingly, this did not form one of the priority goals in Tables 4 and 5 , and yet it would manifestly support many of the goals. This is a classic example of an engineered intervention that would deliver multiple benefits, and indeed was used as the primary example by Rogers and Hunt (2019) of how to deliver Birmingham's and Bristol's city visions. In a similar way, volunteering failed to emerge as a high priority, though it would act as a catalyst for delivering on the high-priority goals. Its value as a business-generated opportunity might superficially appear low, yet, as found in the literature, volunteering can affect positively social enterprises. Therefore, in the case of The Lost World it could prove a positive and important addition; and, if this were allied to the maintenance of local green infrastructure ('nurturing one's local place') the business models become more attractive, delivering a wide range of value including: cost savings, greater social cohesion, H\&WB bene- fits from engagement with nature, educational opportunities, improved biodiversity, improved local aesthetics and a better sense of place, encouragement to active travel (further benefitting $\mathrm{H} \& W B$ ), and so on.

Crime, safety, and anti-social behaviour were also identified as a challenge for the area and social cohesion. Stakeholders highlighted the challenge of managing the area due to the extent of unused and dark areas, suggesting these provide space for anti-social activity. The design of schemes to create green and blue corridors would therefore need to take these factors into account and engineer them out. It was pointed out that improvements to the area could also bring benefits for the educational facilities in the surrounding areas, and that these should be consciously 'designed in' at the planning stage. More generally, as a holistic entity The Lost World along with TEP should reach out to local schools and develop joint activities, potentially using the facilities on site as learning hubs. Volunteering could likewise play a part in this.

It was also interesting to note that local government policy and strategy were considered to be of lower priority, though it was suggested that this was due to the lack of local government funding reaching The Lost World. Additionally, access from and connection to central Birmingham was also considered to present limitations: this area could easily be overlooked because of its detachedness. These comments were evidenced by the lack of direct connection to the Government's New Industrial Strategy, with Birmingham City Council's plans for the 2022 Commonwealth Games, and with The Canal and River Trust's strategy. Addressing this lack of integration into such planning should be a priority for local governance and councillors.

Drawing these observations together, it was suggested that an overarching green and wellbeing agenda to improve living in the area is also currently missing from local policy. This should form a central argument in the push to deliver aspirational change since it would provide the foundation for multiple forms of value generation, as advocated by Rogers and Hunt (2019). Although it was agreed by most in the room that a wellbeing agenda is needed in The Lost World, the stakeholders found it difficult to see how to bring this about, especially at the stage where a collective agreement on what should be done is still underway. Nevertheless, the workshop sessions uncovered many strands that might feature. 


\section{Discussion}

This research aimed to answer the question of how SSM can play a part in the creation of social enterprise business models for green infrastructure and take advantage of local 'heritage' assets, illustrated with a case study based on The Lost World. The research reviewed existing literature around a systems approach using SSM applied to social enterprises and found that there was a strong focus on addressing management and environmental issues. Our research investigated how SSM could be used to create new business models for The Lost World and hence to bring about change. Traditionally, those businesses that currently depend on the availability of external funding adopt a fiscal 'return on investment' focus. They tend to concentrate on land development (hence increased land value), yet this can lead to adverse consequences (i.e., disbenefits, lost opportunities, or negative value) for the future of the urban area and local communities.

It was for this reason that a social enterprise approach was explored, which requires a participatory, democratic, and transparent process in which the 'whys' and 'hows' are explored with stakeholders to develop solutions and decision-making (Crucke \& Knockaert, 2016; Lee et al., 2016; Sánchez-García et al., 2019). To support this a mapping exercise was carried out with stakeholders to understand the efficacy of the application and provide an alternative and documented methodological approach into the SSM (Moldavska \& Welo, 2016; Patel \& Mehta, 2016), taking specific cognisance of the multiple challenges presented by the local context (Hanafizadeh \& Ghamkhari, 2018).

This initial work proved effective in providing the foundations necessary for collective discussion and in attracting all of the key stakeholders in our case study site to engage in the research via a series of workshop sessions. We therefore recommend this as an approach that can be used no matter what the context or goal, noting that the process itself led to benefits in terms of local stakeholder cohesion. Building on this, we trialled the use of SSM to develop collective, evidence-based business models for the sustainable future of The Lost World. The workshop sessions revealed shared values amongst the local stakeholders that could serve as the core proposition for (a) business(es) and identified a series of opportunities for value creation, including social, environmental, educational, H\&WB, and economic (e.g., attracting visitors) benefits. Integrating these benefits and setting them against the costs, and any other adverse consequences, of making the changes necessary to realise the vision for The Lost World would constitute the initial 'business models'--the framework that balances positive outcomes against negative outcomes (one of which is that a financial investment would need to be made) associated with the changes.

Each of the proposed changes (e.g., creation of a community hub, creation of interconnected green corri- dors linking to the river and canal) would be associated with its own set of benefits, costs and other consequences, of course, and each could then undergo iteration. For example, in the case of creation of interconnected green corridors there would be both a capital cost and a maintenance cost, and yet if local volunteers were to engage in maintenance then the latter cost would be reduced to that associated with training and equipping a group of local volunteers and the business case would be stronger. Such iteration of designs and business models (to enhance benefits and/or reduce costs) lies at the heart of the UKCRIC methodologies detailed in Table 1 (Rogers, 2018).

Alongside the opportunities, the workshop revealed some local challenges that might not have been (fully) appreciated (e.g., crime, safety, pockets of unused and 'dark' areas that could accommodate anti-social behaviour). Identifying and surfacing such opportunities and local challenges is useful to inform the SSM value map further and refine designs and business models. It is only when this holistic iteration is complete should the 'case for change' be articulated (Rogers, 2018), founded on a comprehensive, transparent and accessible evidence base and supported by equally comprehensive, transparent and accessible business models, hence helping to remove uncertainty and de-risk decision-making. Work on analysing and aligning all forms of governance to ensure the business models work can then be undertaken. The formal forms of governance (e.g., legislation, regulations, codes \& standards, taxation, and incentives) and informal forms of governance (e.g., individual and societal attitudes and behaviours, social norms, practice norms, etc.) both need to be considered to determine what might limit the success of the changes being proposed.

The research has resulted in the following recommendations:

- Application of SSM should be an iterative process. The first stage, reported herein, required considerable prior research and analysis, yet provided rich datasets and information, and a development of understanding and trust amongst stakeholders, that would enable firm proposals to be created with confidence. Once these have been created, and ensuring that the designs are co-created with the relevant stakeholders, a second workshop is suggested to provide more specifically-targeted discussions on the proposals and explore further the issues that emerged in the first workshop, such as how funding can generate social entrepreneurship for the detailed proposals.

- More specifically, the above research provides the foundation for the creation of new initiatives (or 'businesses') to support the development of The Lost World. These should now be explored with stakeholders, both as traditional urban development proposals (though with a stronger, and far 
wider, articulation of the multiple benefits that they have the potential to generate) and social enterprises. The business models and case for change will reflect the multiple benefits identified and support the discussions.

- There is a need to provide examples of previous business models that have been created and tested at the urban scale (i.e., one that is large enough to embrace the influence of green infrastructure and heritage assets) to generate evidence of the successes and failures, with a particular emphasis on whether, and how well, they have supported the various local stakeholders' vision/missions.

- There is a need to develop and provide examples of the application of SSM. The synthesis of the current limitations and opportunities identified in the first Lost World workshop, and reported above, is a good example of the detail required.

- The workshop was facilitated by researchers who have a deep appreciation of the literature, methodologies and their implementation in practice, and who were able to carry out the prior work. Accepting that such support will not usually be available, there is a compelling need for socialenterprise entrepreneurs to act as catalysts and long-term enablers of the formulation and maintenance of such businesses and business modelsthese are the vital missing actors in the ambition to transform urban areas to benefit the people who live and work there. Recognising this need, and providing training to create such a capability, is therefore important.

\section{Conclusions}

This research aimed to explore how social enterprise can generate value and whether application of the SSM would help define the multiple forms of value that would provide the foundation for new, broader business models to support change. The research focussed on the opportunities offered by largely overlooked and undervalued greenspace and heritage assets in a major city. A large cohort of relevant stakeholders were convened in a workshop in which the SSM approach was adopted and this was found to provide a useful framework for the development of business models for improvements in the Tyseley area of Birmingham, UK. Stakeholders explored common interests and visions and identified opportunities, and limitations, for value generation associated with development of The Lost World, an area of green and blue space within a heavily developed, mixed-use area of Birmingham, yet one with a rich industrial heritage, lying approximately four miles from the city centre. Opportunities for value generation included social, environmental, educational, and $H \& W B$, as well as economic, benefits, while communication, funding, safety, and governance issues were raised as some of the challenges that would need to be addressed.
The research demonstrated that the crucial first stage of the process of creating synergistic change to a deprived area of a city could be achieved via a single workshop primed with considerable prior work. Indeed, the level of participation showed that local communities and businesses would like to be part of a local enterprise approach to develop business models that would enhance and sustain their local area. It also demonstrated the need for stakeholder involvement from conception and throughout every stage of the business development if the greatest value (fullest set of benefits, and delivery of the broadest set of stakeholder visions) is to be achieved. Building on the foundations of this first stage, specific proposals can now be developed with confidence to advance the development of The Lost World via what might be termed sustainable green infrastructure and community businesses.

The Lost World is representative of overlooked or forgotten areas of land that seem to have no sustainable future-areas that remain unused, do not attract funding, potentially facilitate anti-social behaviour, and become a barrier to social cohesion. In the case of The Lost World there is an impetus and energy from local actors to make positive changes, and this allowed the research team to build on its long history of research into sustainable, resilient, and liveable cities to apply its thinking, experience, and methodologies to explore how this change could be made to greatest effect. However, recognising that this type of support will not usually be available, the research has demonstrated a compelling need for social-enterprise entrepreneurs to act as catalysts and long-term enablers of such beneficial change. They would be tasked with carrying out the prior work on the place in question and setting in motion the sequences of activities and methodologies described above, leading to the formulation and sustainment of businesses and business models needed to support the change. We conclude, therefore, that social-enterprise entrepreneurs are the vital missing actors in the ambition to transform urban areas to benefit the people who live and work there.

\section{Acknowledgments}

The authors gratefully acknowledge the financial support of the UK Engineering and Physical Sciences Research Council (EPSRC) and the Economic and Social Sciences Research Council (ESRC) under grant numbers EP/J017698 (Liveable Cities: Transforming the Engineering of Cities to Deliver Societal and Planetary Wellbeing), EP/K012398 (iBUILD), EP/P002021 (Urban Living Birmingham), EP/R017727 (UK Collaboratorium for Research on Infrastructure and Cities Coordination Node) and MR/T045353 (REPLENISH: REimagining PLaces and ENgineered Infrastructure Systems for Health). The research programme was led by Professor Rogers at the University of Birmingham with the university's support; the additional support from Lancaster 
University, Birmingham City University and the Hay Mills Foundation Trust is also gratefully acknowledged.

\section{Conflict of Interests}

The authors declare no conflict of interests.

\section{References}

Ackers Adventure. (2020). Homepage. Ackers Adventure. Retrieved from www.ackers-adventure.co.uk

Ahlström, H., Williams, A., \& Vildåsen, S. (2020). Enhancing systems thinking in corporate sustainability through a transdisciplinary research process. Journal of Cleaner Production, 256, 120691.

Akemu, O., Whiteman, G., \& Kennedy, S. (2016). Social enterprise emergence from social movement activism: The fairphone case. Journal of Management Studies, 53, 846-877.

Altinay, L., Sigala, M., \& Waligo, V. (2016). Social value creation through tourism enterprise. Tourism Management, 54, 404-417.

Arup. (2014). Cities alive: Rethinking green infrastructure. London: Arup.

Bedinger, M., Beevers, L., Walker, G. H., Visser-Quinn, A., \& McClymont, K. (2020). Urban systems: Mapping interdependencies and outcomes to support systems thinking. Earth's Future, 8(3), e2019EF001389.

Berry, H. L., Waite, T. D., Dear, K. B. G., Capon, A. G., \& Murray, V. (2018). The case for systems thinking about climate change and mental health. Nature Climate Change, 8, 282-290.

Birmingham City Council. (2017). Birmingham plan 2031: Birmingham development plan-Planning for sustainable growth. Birmingham: Birmingham City Council.

Birmingham City Council. (2019). Birmingham health profile 2019. Birmingham: Birmingham City Council.

Birmingham Education Partnership. (2020). About. Birmingham Education Partnership. Retrieved from https://bep.education/about

Birmingham Energy Institute. (2020). Changing the way we deliver, consume and think about energy. University of Birmingham. Retrieved from https://www. birmingham.ac.uk/research/energy/index.aspx

Birmingham Open Spaces Forum. (2020). Homepage. Birmingham Open Spaces Forum. Retrieved from https://bosf.org.uk

Bontis, N., Ciambotti, M., Palazzi, F., \& Sgro, F. (2018). Intellectual capital and financial performance in social cooperative enterprises. Journal of Intellectual Capital, 19(49), 712-731.

Bouch, C. J., \& Rogers, C. D. F. (2017). A systems thinking approach to the development of alternative infrastructure business models. In Proceedings of International Symposium for Next Generation Infrastructure (ISNGI-2017) (pp. 55-63). London: ISNGI.

Bouch, C. J., Rogers, C. D. F., Powell, M. J., \& Horsfall, D. A.
C. (2018). Developing alternative business models for smart infrastructure: A UK case study. Proceedings of the Institution of Civil Engineers--Smart Infrastructure and Construction, 171(2), 77-87.

Breuste, J., Artmann, M., Li, J., \& Xie, M. (2014). Special issue on green infrastructure for urban sustainability. Journal of Urban Planning and Development, 141.

Bryson, J. R., Mulhall, R. A., Song, M., Loo, B. P. Y., Dawson, R. J., \& Rogers, C. D. F. (2018). Alternativesubstitute business models and the provision of local infrastructure: Alterity as a solution to financialization and public-sector failure. Geoforum, 95, 25-34.

Caceres, P. A., \& Wiesenborn, J. B. (2019). A bridge for two views: Checkland's soft systems methodology and Maturana's ontology of the observer. Journal of the Operational Research Society, 71(4), 660-672.

Canal and River Trust. (2020). About us. Canal and River Trust. Retrieved from https://canalrivertrust.org.uk/ about-us

Caparros-Midwood, D., Barr, S., \& Dawson, R. J. (2017). Spatial optimization of future urban development with regards to climate risk and sustainability objectives. Risk Analysis, 37(11), 2164-2181.

Cavada, M., Hunt, D. V. L., \& Rogers, C. D. F. (2016). Do smart cities realise their potential for lower $\mathrm{CO}_{2}$ emissions? Proceedings of the Institution of Civil Engineers--Engineering Sustainability, 169(6), 243-252.

Cavada, M., Hunt, D. V. L., \& Rogers, C. D. F. (2017). The role of infrastructure in smart cities. In Proceedings of International Symposium for Next Generation Infrastructure (ISNGI 2017) (pp. 80-88). London: ISNGI.

Centre for Cities. (2019). Cities outlook 2019. Centre for Cities. Retrieved from https://www.centreforcities. org/reader/cities-outlook-2019/a-decade-ofausterity

Checkland, P. B., \& Haynes, M. G. (1994). Varieties of systems thinking: The case of soft systems methodology. Systems Dynamic Review, 10, 189-197.

Checkland, P. B., \& Scholes, J. (1999). Soft systems methodology in action. Hoboken, NJ: Wiley.

Choudrie, J., \& Zamani, E. (2016). Understanding individual user resistance and workarounds of enterprise social networks: The case of Service Ltd. Journal of Information Technology, 31, 130-151.

Church of England. (2020). About us. A Church Near You. Retrieved from https://www.achurchnearyou.com/ church/7326/about-us

Crucke, S., \& Knockaert, M. (2016). When stakeholder representation leads to faultlines: A study of board service performance in social enterprises. Journal of Management Studies, 53, 768-793.

Defra. (2018). A green future: Our 25 year plan to improve the environment. London: Department for Environment Food and Rural Affairs.

Dey, P., \& Teasdale, S. (2016). The tactical mimicry of social enterprise strategies: Acting 'as if' in the every- 
day life of third sector organizations. Organization, 23(4), 485-504.

Emam, L. (2016). Social business models: Effectuation in action (Doctoral dissertation). Liverpool University, Liverpool, UK.

Environment Agency. (2020). What the Environment Agency does. Gov.UK. Retrieved from https://www. gov.uk/government/organisations/environmentagency

Faccioli, M., McVittie, A., Glenk, K., \& Blackstock, K. (2018). Natural capital accounts: Review of available data and accounting options. Dundee: The James Hutton Institute.

González, A. M., Sandoval, H., Acosta, P., \& Hena, F. (2016). On the acceptance and sustainability of renewable energy projects: A systems thinking perspective. Sustainability, 8(11), 1171.

Gray, S., Sterling, E. J., Aminpour, P., Goralnik, L., Singer, A., Wei, C., . . Norris, P. (2019). Assessing (socialecological) systems thinking by evaluating cognitive maps. Sustainability, 11(20), 5753.

Gu, Y., Deal, B., \& Larsen, L. (2018). Geodesign processes and ecological systems thinking in a coupled humanenvironment context: An integrated framework for landscape architecture. Sustainability, 10(9), 3306.

Hall, J. W., Tran, M., Hickford, A. J., \& Nicholls, R. J. (Eds.). (2016). The future of national infrastructure: $A$ system of systems approach. Cambridge: Cambridge University Press.

Hanafizadeh, P., \& Ghamkhari, F. (2018). Elicitation of tacit knowledge using soft systems methodology. Systemic Practice and Action Research, 32(5), 521-555.

Hay Mills Foundation Trust. (2020). The Hay Mills Foundation Trust. Webster \& Horsfall. Retrieved from https://www.whgroup.org/history

Henriques, I. (2018). Addressing wicked problems using new business models. Economic Alternatives, 4, 463-466.

Hoelzinger, O., \& Grayson, N. (2019). Birmingham health economic assessment and natural capital accounts: Revealing the true cost of council-managed parks and green estate. Birmingham: Birmingham City Council.

Honeybone, P., Collins, B. S., Barnes, K., \& Cosgrave, E. (2018). The little book of governing the city. Birmingham: Liveable Cities.

House of Commons. (2017). Public parks: Seventh report of session 2016-17. London: House of Commons.

Inspired Steps. (2020). Inspired steps: A community interest company. Inspired Steps. Retrieved from https:// www.inspiredsteps.co.uk

Ives, M. C., Simpson, J. M., \& Hall, J. W. (2018). Navigating the water trilemma: A strategic assessment of longterm national water resource management options for Great Britain. Water and Environment Journal, 32(4), 546-555.

Király, G., Köves, A., \& Balázs, B. (2017). Contradictions between political leadership and systems thinking. Journal of Cleaner Production, 40(1), 134-143.
Kish, K., Bunch, M. J., \& Xu, B. J. (2016). Soft systems methodologies in action: Environment, health \& Shanghai's elderly. Systemic Practice and Action Research, 29, 61-77.

Leach, J. M., Braithwaite, P. A., Lee, S. E., Bouch, C. J., Hunt, D. V. L., \& Rogers, C. D. F. (2016). Measuring urban sustainability and liveability performance: The City Analysis Methodology (CAM). International Journal of Complexity in Applied Science and Technology, 1(1), 86-106.

Leach, J. M., Lee, S. E., Hunt, D. V. L., \& Rogers, C. D. F. (2017). Improving city-scale measures of livable sustainability: A study of urban measurement and assessment through application to the city of Birmingham, UK. Cities, 71, 80-87.

Leach, J. M., Mulhall, R., Rogers, C. D. F., \& Bryson, J. R. (2019). Reading cities: Developing an urban diagnostics approach for identifying integrated urban problems with application to the city of Birmingham, UK. Cities, 86, 136-144.

Leach, J. M., Rogers, C. D. F., Ortegon, A., \& Tyler, N. (2019). The liveable cities method: Establishing the case for transformative change. Proceedings of the Institution of Civil Engineers-Engineering Sustainability, 173(1), 8-19.

Lee, K.-H., Herold, D. M., \& Yu, A.-L. (2016). Small and medium enterprises and corporate social responsibility practice: A Swedish perspective. Corporate Social Responsibility Environmental Management, 23, 88-99.

Lombardi, D. R., Leach, J. M., Rogers, C. D. F., Barber, A. R. G., Barnes, M., Boyko, C. T., ... Wyatt, J. D. (2012). Designing resilient cities: A guide the good practice. Bracknell: IHS BRE Press.

Moldavska, A., \& Welo, T. (2016). Development of manufacturing sustainability assessment using systems thinking. Sustainability, 8(1), 5.

Mora, L., \& Deakin, M. (2019). Untangling smart cities: From utopian dreams to innovation systems for a technology enabled urban sustainability. Oxford: Elsevier.

Naumann, S., McKenna, D., Kaphengst, T., Pieterse, M., \& Rayment, M. (2011). Design, implementation and cost elements of Green Infrastructure projects (Report No. 070307/2010/577182/ETU/F.1). Washington, DC, and Fairfax, VA: Ecologic institute and GHK Consulting.

ND Landscape Architects Ltd. (2020). Who are we? ND Landscape Architects. Retrieved from https://ndla.co. uk

Nguyen, T. T. N., Scognamillo, D. G., \& Comer, C. E. (2019). Revealing community perceptions for ecological restoration using a soft system methodology. Systemic Practice and Action Research, 32, 429-442.

Onat, N. C., Kucukvar, M., Halog, A., \& Cloutier, S. (2017). Systems thinking for life cycle sustainability assessment: A review of recent developments, applications, and future perspectives. Sustainability, 9(5), 706. 
Patel, S., \& Mehta, K. (2016). Systems, design, and entrepreneurial thinking: Comparative frameworks. Systemic Practice and Action Research, 30, 515-533.

Pollastri, S., Dunn, N., Cooper, R. F. D., Boyko, C. T., Tyler, N., \& Rogers, C. D. F. (2018). Envisioning urban futures as conversations to inform design and research. Proceedings of the Institution of Civil Engineers--Urban Design and Planning, 171(4), 146-156.

Powell, M., Glendinning, S., \& Dawson, R. J. (2018). Drain covers and door steps: Decision making and the cocreation of future cities. Proceedings of the Institution of Civil Engineers--Urban Design and Planning, 171(4), 177-186.

Rogers, C. D. F. (2018). Engineering future liveable, resilient, sustainable cities using foresight. Proceedings of the Institution of Civil Engineers-Civil Engineering, 171(6), 3-9.

Rogers, C. D. F., \& Hunt, D. V. L. (2019). Realising visions for future cities: An aspirational futures methodology. Proceedings of the Institution of Civil EngineersUrban Design and Planning, 172(4), 125-140.

Rogers, C. D. F., Lombardi, D. R., Leach, J. M., \& Cooper, R. F. D. (2012). The urban futures methodology applied to urban regeneration. Proceedings of the Institution of Civil Engineers-Engineering Sustainability, 165(1), 5-20.

Rogers, C. D. F., Shipley, J., Blythe, P., Braithwaite, P. A., Brown, C., Collins, B. S., . . Leach, J. M. (2014). Future urban living: A policy commission investigating the most appropriate means for accommodating changing populations and their needs in the cities of the future. Birmingham: University of Birmingham.

Sánchez, G. R., Bolívar, M. P., \& Hernández, L. A. M. (2017). Corporate and managerial characteristics as drivers of social responsibility disclosure by stateowned enterprises. Review of Managerial Science, 11, 633-659.

Sánchez-García, J. Y., Ramírez-Gutiérrez, A. G., NúñezRíos, J. E., Cardoso-Castro, P. P., \& Rojas, O. G. (2019). Systems thinking approach to sustainable performance in RAMSAR sites. Sustainability, 11(22), 6469.

Seanor, P., Bull, M., \& Ridley-Duff, R. (2007). Contradictions in social enterprise: Do they draw in straight lines or circles? Paper presented at the Institute for Small Business and Entrepreneurship Conference, Glasgow, UK.

Sullivan, S. (2014). The natural capital myth; or will accounting save the world? Preliminary thoughts on nature, finance and values (Working Paper No. 3). Manchester: The Leverhulme Centre for the Study of Value, School of Environment, Education and Development.

Tracey, P., \& Philips, N. (2015). Managing the consequences of organizational stigmatization: Identity work in a social enterprise. Academy of Management, 59(3), 740-765.

Tyseley Energy Park. (2020). Our history. Tyseley Energy Park. Retrieved from https://www.tyseleyenergy.co. uk/our-history

United Kingdom Collaboratorium for Research on Infrastructure and Cities. (2021). Making informed infrastructure decisions. UKCRIC. Retrieved from www.ukcric.com/insights/making-informedinfrastructure-decisions

Upward, A., \& Jones, P. (2016). An ontology for strongly sustainable business models: Defining an enterprise framework compatible with natural and social science. Organization \& Environment, 29(1), 97-123.

Vintage Trains. (2020). Vintage trains. Birmingham Heritage Forum. Retrieved from http://birmingham heritage.org.uk/railway.html

West Midlands Police. (2020). Our vision and values. West Midlands Police. Retrieved from https://westmidlands.police.uk/about-us/vision-and-values

Williams, A., Kennedy, S., Philipp, F., \& Whiteman, G. (2017). Systems thinking: A review of sustainability management research. Journal of Cleaner Production, 148, 866-881.

Wilson, A., Tewdwr-Jones, M., \& Comber, R. (2019). Urban planning, public participation and digital technology: App development as a method of generating citizen involvement in local planning processes. Environment and Planning B: Urban Analytics and City Science, 46(2), 286-302.

Wry, T., \& York, J. (2015). An identity based approach to social enterprise. The Academy of Management Review, 42(3), 437-460.

Zahra, S., Gedajlovic, E., Neubaum, D., \& Shulman, J. (2009). A typology of social entrepreneurs: Motives, search processes and ethical challenges. Journal of Business Venturing, 24(5), 519-532.

Zott, C., \& Amit, R. (2010). Business model design: An activity system perspective. Long Range Planning, $43(2 / 3), 216-226$.

\section{About the Authors}

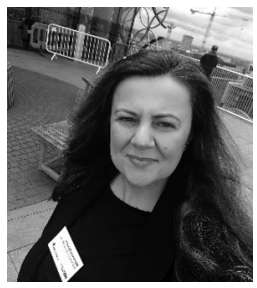

Marianna Cavada is a Lecturer in Urban Design Policy at Imagination Lancaster; School of Architecture, Lancaster Institute for Contemporary Arts. Her research is focusing on smart cities, urban systems engineering, and design for urban policy She holds a BA Hons, Dip Arch in Architecture (Higher Commendation) and a PhD in Civil Engineering from the Engineering Department, University of Birmingham, UK. She practiced Architecture and has been involved in large urban developments in the UK, UAE, and China. 

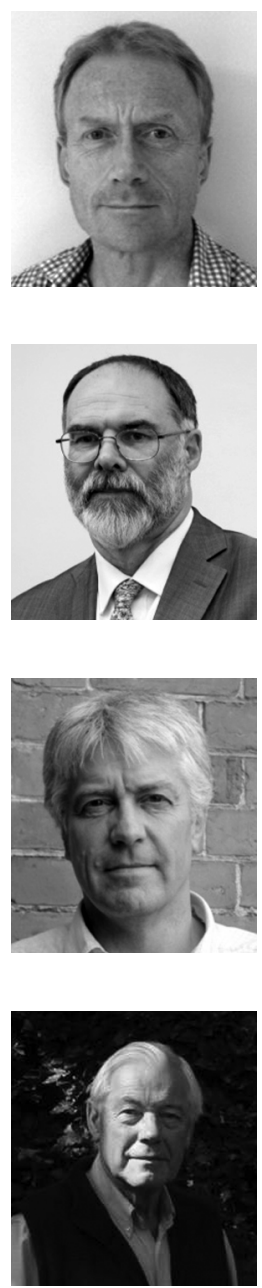

Chris Bouch is a Chartered Civil Engineer with a Masters in Railway Systems Engineering, worked for 20 years in the design and construction industry currently a Senior Research Fellow at the University of Birmingham. He is focusing on the application of systems engineering and systems thinking to the exploration of liveable, sustainable and resilient future cities and the development of a methodology for the creation of business models to support financing and funding of infrastructure, including green and blue infrastructures.

Chris Rogers is a Professor of Geotechnical Engineering at the University of Birmingham. He researches urban sustainability, resilience and liveability of cities, and the infrastructure systems that support them. He chairs the Institution of Civil Engineers Research, Development \& Innovation towards Engineering Excellence Panel, is Director of Research Integration for the UK Collaboratorium for Research on Infrastructure and Cities (UKCRIC) and is Director of UKCRIC's National Buried Infrastructure Facility at Birmingham.

Michael Grace is a Senior Research Fellow within the Faculty of Computing, Engineering and the Built Environment at Birmingham City University. Mike has experience in environmental and development planning and green infrastructure in national and local government. His multi-disciplinary research includes the RCUK/Innovate UK funded Urban Living Birmingham project, a review of NERC's Green Infrastructure Innovation Programme and he is currently trialling the national Green Infrastructure Standards Draft Framework for Defra.

Alexander Robertson is a Trustee and the Archivist for the Hay Mills Foundation Trust. In collaboration with Birmingham City Council Archives and the Heritage Department, the Trust is conducting detailed research into Webster and Horsfall's 300-year history. Volunteers are working with Sandy to record the impact of the company on the people who worked there and on the wider Birmingham area. It will also detail the lasting global legacy the company has left on the industrial world. 